\title{
ES KRIM KEDELAI HITAM (Glycine soja l) DENGAN PENAMBAHAN LIDAH BUAYA (Aloe vera)
}

\author{
Black Soybean Ice Cream (Glycine soja l) \\ with Addition Of Aloe Vera Gel (Aloe vera)
}

\author{
Roni Sanjaya ${ }^{1)}$, Nanik Suhartatik ${ }^{1)}$, Yustina Wuri Wulandari ${ }^{1)}$ \\ Fakultas Teknologi dan Industri pangan Universitas Slamet Riyadi Surakarta, \\ Jl. Sumpah Pemuda 18 Joglo Kadipiro Surakarta 57136 \\ Email: ronisansan@gmail.com
}

\begin{abstract}
ABSTRAK
Es krim adalah salah satu produk olahan yang menggunakan susu sebagai bahan dasar dan berbentuk beku. Penelitian ini menggunakan kedelai hitam sebagai bahan dasar pembuatan es krim. Kedelai hitam kaya akan protein yang dapat menggantikan bahan baku pembuatan es krim berupa susu sapi. Penelitian ini juga menggunakan lidah buaya sebagai bahan tambahan yang dapat meningkatkan kualitas es krim. Penelitian ini bertujuan untuk menentukan es krim kedelai hitam dengan penambahan lidah buaya terbaik ditinjau dari sifat sensorisnya. Selain itu juga untuk mengetahui karakteristik es krim kedelai hitam dengan penambahan lidah buaya meliputi: sifat fisik (overrun), sifat kimia (protein, lemak, dan total padatan), dan sifat fungsional (aktivitas antioksidan). Penelitian dilakukan dengan Rancangan Acak Lengkap (RAL) faktorial yang terdiri dari 2 faktor. Faktor pertama adalah konsentrasi kedelai hitam $(5,15,25 \%)$ sedangkan faktor yang kedua variasi konsentrasi lidah buaya $(1,5 ; 3 ; 4,5 \%)$. Hasil penelitian menunjukan bahwa kombinasi perlakuan konsentrasi kedelai hitam dengan lidah buaya, dengan konsentrasi kedelai hitam 25\% dan lidah buaya 4,5\% merupakan perlakuan terbaik didasarkan pada kesukaan keseluruhan yang terdapat pada es krim. Pada perlakuan ini dihasilkan aktivitas antioksidan es krim kedelai hitam dengan penambahan lidah buaya sebesar DPPH 36,60\%, kadar protein 9,42\%, kadar lemak 4,62\%, total padatan terlarut $29,33 \%$, kecepatan meleleh 15,08 menit/1o gram, overrun $23,39 \%$ serta uji organoleptik terhadap warna 3,73 (kuning kehijaun), aroma langu 1,73 (tidak terlalu tinggi), tekstur 3,13 (lembut), dan kesukaan keseluruhan 3,53 (paling disukai).
\end{abstract}

Kata kunci: Es krim, kedelai hitam, lidah buaya.

\begin{abstract}
Ice cream is one of processed products that uses milk as a basic ingredient and been frozen. This study used black soybeans as the basic ingredient in the ice cream. Black soybeans are rich in protein which can replace the raw material. This research also uses Aloe vera as an additional ingredient that can improve the quality of the ice cream. This study aimed to determine the best black soybean ice cream with the addition of Aloe vera in terms of its sensory properties. In addition, to find out the characteristics of black soybean ice cream with the addition of Aloe vera include: physical properties (overrun), chemical properties (protein, fat, and total solids), and functional properties (antioxidant activity). The study was conducted in a factorial Completely Randomized Design (RAL) consisting of 2 factors. The first factor was the concentration of black soybeans $(5,15,25 \%)$ while the second factor was the variation in concentration of Aloe vera $(1.5 ; 3 ; 4.5 \%)$. The results showed that the combination of $25 \%$ black soybeans and $4.5 \%$ aloe vera was the best treatment based on the overall preference found in ice cream. In this treatment the antioxidant activity of black soybean ice cream produced with the addition of Aloe vera was 36.60\% DPPH, $9.42 \%$ protein, $4.62 \%$ fat, $29.33 \%$ of total dissolved solids, 15.08 minutes / 10 grams melting speed, $23.39 \%$ overrun and organoleptic test for color
\end{abstract}


3.73 (greenish yellow), fresh aroma 1.73 (not too high), texture 3.13 (soft), and overall preference 3.53 (most preferred).

Keywords: Ice cream, black soybeans, aloe vera

\section{PENDAHULUAN}

Pola konsumsi di masyarakat yang semakin beraneka ragam seperti lebih memilih mengkonsumsi makanan dan minuman instan menimbulkan berbagai macam penyakit berbahaya seperti penyakit kanker yang merupakan salah satu penyebab kematian terbesar di dunia. Selain konsumsi obat obatan yang tergolong yang akan menimbulkan resiko lain, maka salah satu cara adalah dengan mengkonsumsi makanan dan minuman yang mengandung zat gizi yang penting dan menyehatkan tubuh. Salah satu bahan pangan yang dapat dimanfaatkan adalah kedelai hitam (Glycine soja L.) (Sieb. E Zucc.) karena mengandung asam amino esensial, vitamin $\mathrm{E}$, saponin, dan kaya akan antioksidan misalnya dengan flavonoid, isoflavon, dan antosianin (Hasler, 1998).

Pemanfaatan di Indonesia kedelai hitam untuk memenuhi kebutuhan pangan sudah dilakukan masyarakat tetapi masih sangat terbatas penggunaannya. Dengan teknik pengolahan kedelai hitamyang masih sederhana, kebanyakan kedelai hitam hanya digunakan sebagai bahan baku pembuatan kecap. Sampai saat ini belum ada pengolahan dan kreasi kedelai hitam menjadi produk makanan yang menarik seperti es krim, hal ini dikarenakan kurangnya pengetahuan masyarakat Indonesia tentang pemanfaatan kedelai hitam tersebut. Untuk itu perlu ditingkatkan lagi penganekaragaman pangan, salah satunya dengan mengolah kedelai hitam menjadi es krim.

Es krim adalah produk olahan susu yang berbentuk beku yang ditambahkan dengan pemanis, penstabil, dan pengemulsi (Suharyanto, 2009). Indonesia merupakan konsumen es krim yang tertinggi di Asia Tenggara yaitu sebesar 158 juta liter/tahun. Faktor utama dalam pertumbuhan konsumsi es krim adalah kondisi cuaca di Indonesia yang panas dan pertumbuhan jumlah penduduk yang diikuti dengan peningkatan daya beli (Santi, 2017).

Es krim adalah salah satu makanan yang bernilai gizi tinggi namun rendah serat yaitu o\% serat. Sumbangan nilai gizi terbesar pada es krim berasal dari bahan baku dasarnya yaitu susu, itu sebabnya es krim memiliki nilai gizi tinggi dibandingkan dengan jenis minuman lainnya. Para peneliti menemukan lebih dari 100.00o jenis molekul yang terkandung di dalam susu yaitu air, lemak, protein, karbohidrat, mineral, enzim-enzim, gas, serta vitamin A, $C$ dan D (Inges, 2009). Secara umum es krim yang baik memiliki tekstur yang lembut, tidak mudah meleleh, dan berkenampakan stabil antara lemak dan air. Es krim yang rendah asam lemaknya akan menyebabkan es krim kurang stabil dan mudah meleleh. Dari hal itu perlu adanya penambahan emulsifier dan bahan penstabil. Penambahan emulsifier dapat dilakukan dengan penambahan kuning telur karena banyak mengandung lesitin. Penambahan bahan penstabil dapat dilakukan dengan pemberian CMC, bahan - bahan yang mengandung pektin, dan alginat.

Lidah buaya adalah tanaman yang banyak mengandung polisakarida dan dapat digunakan sebagai bahan penstabil pada es krim (El-Zairy, 2011). Menurut Yanuarda (2014), gel lidah buaya dapat mempengaruhi kecepatan meleleh pada es krim. Lidah buaya juga mempunyai kandungan nutrisi cukup lengkap antara lain vitamin, mineral, asam amino dan enzim. Banyak kelebihan dan potensi sebagai bahan pangan karena semua bagian dari tanaman dapat dimanfaatkan. Bagian-bagian lidah buaya yang digunakan antara lain daun, getah daun, dan gel bening (Furnawanthi, 2002). Potensi ini sebenarnya sudah mulai dikembangkan namun sampai saat ini belum termanfaatkan secara maksimal. Berdasarkan hasil penelitian Furnawanthi, (2002) tanaman lidah buaya mempunyai begitu banyak manfaat untuk 
kesehatan, maka penggunaan lidah buaya yang semakin bervariasi akan meningkatkan nilai ekonomi dan selera konsumen terhadap lidah buaya.

Pada penelitian ini bertujuan untuk mengetahui formulasi dari es krim kedelai hitam yang ditambahkan lidah buaya, dan untuk mengetahui penambahan sari kedelai dan lidah buaya terhadap sifat organoleptik warna, aroma, rasa, tekstur dan kesukaan es krim, mengetahui kandungan zat gizi yang meliputi, protein, antioksidan, lemak dalam es krim sari kedelai hitam dan lidah buaya terbaik dari hasil uji kimia.

\section{METODE PENELITIAN}

Alat

Alat yang digunakan dalam penelitian ini antara lain: blender (Philip), gelas ukur (Pyrex), erlenmeyer (Pyrex), (spektofotometer Genesys ${ }_{10 S} U V$-VIS , pipet volum $1 \mathrm{ml}$, beker glass (Pyrex), waterbath ex RRC, tabung reaksi 16xi6o mm merk duran, rak tabung) .

\section{Bahan}

Bahan yang digunakan dalam penelitian yaitu susu kedelai hitam, gula, susu skim, tepung maizena, vanili, ovalet, lidah buaya, yang diperoleh dari pasar, sedangkan bahan untuk analisis kimia antara lain 1,1,2,2-Diphenyl Picryl Hydrazyl o,1 mN, Larutan Nelson 5\%, Arsenomolibdat 5\%, aquadest, larutan BSA, etanol $95 \%$.

\section{Rancangan Percobaan}

Penelitian ini menggunakan Rancangan Acak Lengkap (RAL) faktorial, dengan dua faktor yaitu faktor pertama rasio kedelai hitam (5\%, 15\%, dan $25 \%)$ dan faktor kedua lidah buaya ( $1,5 \%$; $3 \%$; dan $4,5 \%)$.

Rancangan tersebut akan memperoleh 9 kombinasi perlakuanmasing-masing perlakuan diulang sebanyak dua kali. Data yang diperoleh dianalisis dengan uji sidik ragam pada jenjang nyata 0,05. Jika adabeda nyata dilanjutkan uji Tukey untuk mengetahui beda nyata antar perlakuan pada tingkat signifikansi $5 \%$.

\section{TAHAPAN PENELITIAN}

Pembuatan Jus Lidah Buaya

Lidah Buaya yang dipilih adalah lidah buaya yang baik. Kemudian lidah buaya dikupas, dipotong, dan diambil daging buahnya. Lidah buaya yang sudah dikupas direndam dengan larutan garam dengan konsentrasi o,025\%. Setelah direndam lidah buaya dicuci dengan air bersih. Kemudian lidah buaya yang sudah bersih dikukus selama 10 menit. Lidah buaya yang sudah dikukus lalu didinginkan, setelah itu diblender dan timbang sesuai perlakuan (Sundari dan saati, 2009).

\section{Pembuatan Susu Kedelai Hitam}

Memilih kedelai hitam yang tidak rusak. Kemudian direndam dalam air dingin selama 16 jam. Setelah itu dikukus sekitar 15 menit. Ditimbang sesuai perlakuan $(5,15,25$ gram). Kemudian digiling dengan blender dan ditambah air 5ooml. Terakhir disaring dengan saringan.Susu kedelai hitam siap digunakan sesuai perlakuan (Pramitasari,2010).

\section{Pembuatan Es Krim Kedelai Hitam - Lidah Buaya}

Masukan susu kedelai hitam $450 \mathrm{ml}$, tepung maizena $20 \mathrm{~g}$, gula pasir $100 \mathrm{~g}$, susu skim 50 g, dan vanili 1 g. Diaduk dan dimasak hingga mendidih, jaga jangan sampai susu pecah. Setelah mendidih diangkat dan didinginkan. Kemudian ditambahkan lidah buaya sesuai perlakuan. Dimasukkan dalam freezer selama \pm 2 jam. Ditambah ovalet 5 gram, kemudian di campur menggunakan mixer selama 10 menit hingga lembut dengan kecepatan tinggi. Lakukan hal ini sebanyak 2 kali atau sampai es krim lembut. Pada perlakuan terakhir es krim dibekukan dalam freezer selama \pm 3 jam. Es krim kedelai hitam siap untuk dianalisis. (Putri, 2015).

\section{Cara Pengumpulan Data}

Analisis yang digunakan dalam penelitian ini yaitu analisis kimia, fisika dan uji organoleptik. Analisis kimia dan fisika terdiri dari analisis aktivitas antioksidan dengan metode DPPH (Yen dan Chen, 1995), analisis kadar protein dengan metode Lowry- Folin (Sudarmadji et 
al., 1997), analisis kadar lemak dengan metode Mojohniier (Mojohnier dan Troy, 1973), analisis kecepatan meleleh (Bodyfelt et al., 1998), analisis overrun (Marshall dan Arbuckle, 200o), analisis padatan terlarut menggunakan alat refraktometer Abbe (Pomeranz dan Meloan, 1980) dan uji organoleptik dengan metode scoring test (Kartika et al., 1988) meliputi: warna, rasa, flavor langu, tekstur dan kesukaan keseluruhan.

\section{HASIL DAN PEMBAHASAN Analisis Kimia}

Tabel 1.Rangkuman Hasil Analisis Kimia dan Fisika Es Krim Kedelai Hitam- Lidah Buaya

\begin{tabular}{|c|c|c|c|c|c|c|c|}
\hline \multirow[b]{2}{*}{$\begin{array}{l}\text { Konsentrasi } \\
\text { Kedelai Hitam }\end{array}$} & \multirow[b]{2}{*}{$\begin{array}{c}\text { Konsen- } \\
\text { trasi Lidah } \\
\text { Buaya }\end{array}$} & \multicolumn{6}{|c|}{ Analisis Kimiawi } \\
\hline & & $\begin{array}{c}\text { Aktivitas } \\
\text { Antioksi- } \\
\text { dan DPPH } \\
(\%)\end{array}$ & $\begin{array}{l}\text { Protein } \\
(\%)\end{array}$ & $\begin{array}{c}\text { Lemak } \\
(\%)\end{array}$ & $\begin{array}{c}\text { Padatan } \\
\text { Terlarut } \\
(\%)\end{array}$ & $\begin{array}{c}\text { Kecepatan } \\
\text { Meleleh } \\
(\%)\end{array}$ & $\begin{array}{l}\text { Overrun } \\
(\%)\end{array}$ \\
\hline \multirow[t]{3}{*}{$5 \%$} & $1,5 \%$ & $24,93^{\mathrm{ab}}$ & $3,42^{\mathrm{a}}$ & $1,51^{\mathrm{a}}$ & $28,00^{\mathrm{a}}$ & $8,58^{a}$ & $24,51^{b}$ \\
\hline & $3 \%$ & $23,59^{\mathrm{a}}$ & $3,41^{\mathrm{a}}$ & $1,50^{\mathrm{a}}$ & $28,00^{\mathrm{a}}$ & $11, \mathrm{OO}^{\mathrm{b}}$ & $24,51^{b}$ \\
\hline & $4,5 \%$ & $24,61^{\mathrm{ab}}$ & $3,45^{\mathrm{a}}$ & $1,57^{\mathrm{a}}$ & $28, \mathrm{oO}^{\mathrm{a}}$ & $15,06^{c}$ & $24,51^{b}$ \\
\hline \multirow[t]{3}{*}{$15 \%$} & $1,5 \%$ & $29,80^{a b}$ & $6,61^{b}$ & $3,10^{b}$ & $29,00^{b}$ & $9,02^{\mathrm{ab}}$ & $23,64^{\mathrm{a}}$ \\
\hline & $3 \%$ & $29,00^{\mathrm{ab}}$ & $6,64^{b}$ & $3,14^{b}$ & $29,00^{b}$ & $11,04^{b}$ & $23,64^{\mathrm{a}}$ \\
\hline & $4,5 \%$ & $30,55^{\mathrm{bc}}$ & $6,62^{\mathrm{b}}$ & $3,24^{b}$ & $29,00^{\mathrm{b}}$ & $15,08^{c}$ & $23,64^{\mathrm{a}}$ \\
\hline \multirow[t]{3}{*}{$25 \%$} & $1,5 \%$ & $36,59^{\mathrm{cd}}$ & $9,42^{c}$ & $4,60^{c}$ & $29,33^{c}$ & $9,04^{\mathrm{ab}}$ & $23,39^{\mathrm{a}}$ \\
\hline & $3 \%$ & $37,34^{\mathrm{d}}$ & $9,40^{c}$ & $4,61^{c}$ & $29,33^{\mathrm{c}}$ & $11,00^{\mathrm{b}}$ & $23,39^{a}$ \\
\hline & $4,5 \%$ & $36,60^{\mathrm{cd}}$ & $9,42^{c}$ & $4,62^{c}$ & $29,33^{\mathrm{c}}$ & $15,08^{c}$ & $23,39^{\mathrm{a}}$ \\
\hline
\end{tabular}

Keterangan: Rerata yang diikuti huruf yang berbeda pada kolom yang sama menunjukkan beda nyata pada uji Tukey taraf signifikan

\section{Aktivitas Antioksidan Metode DPPH}

Aktivitas antioksidan tertinggi diperoleh pada es krim kedelai hitam-lidah buaya dari perlakuan kedelai hitam 25\% dan lidah buaya $3 \%$ dengan nilai aktivitas antioksidan $37.34 \%$, sedangkan aktivitas antioksidan terendah diperoleh pada es krim kedelai hitam-lidah buaya dari perlakuan prosentase kedelai hitam $5 \%$ dan lidah buaya 3\% dengan nilai aktivitas antioksidan 23,59\%. Peningkatan aktivitas antioksidan disebabkan oleh adanya senyawa fenolik terutama isoflavon yang ada pada kedelai. Kacang-kacangan, khususnya kedelai sumber utama isoflavon. Isoflavon merupakan senyawa polifenol yang dapat memperlihatkan peranan seperti estrogen yaitu senyawa yang mempunyai kemampuan sebagai antioksidan (Muchtadi, 2010).

\section{Protein}

Kadar protein tertinggi diperoleh pada es krim kedelai hitam-lidah buaya dari perlakuan kedelai hitam 25\%, dan lidah buaya 1,5\% dan 4,5\% dengan kadar protein 9,42\%, sedangkan kadar protein terendah diperoleh pada es krim kedelai hitam-lidah buaya dari perlakuan prosentase kedelai hitam 5\% dan lidah buaya $3 \%$ dengan kadar protein 3,41\%. Kadar protein es krim kedelai hitam-lidah buaya akan cenderung naik dengan semakin bertambahnya kadar kedelai hitam. Hal ini disebabkan karena kedelai hitam memiliki kadar protein sebesar 33,3\% (Somaatmadja, 1985). Dari hasil kadar protein, es krim kedelai hitam-lidah buaya merupakan es krim yang berkualitas baik dalam hal kadar proteinnya. Kadar protein yang tinggi dapat membantu memperbaiki tekstur es krim, membantu pembentukan body pada produk dan meningkatkan overrun.

\section{Lemak}

Kadar lemak tertinggi diperoleh pada es 
krim kedelai hitam-lidah buaya dari perlakuan kedelai hitam $25 \%$ dan lidah buaya 3\% dengan kadar lemak 4.62\%, sedangkan kadar lemak terendah diperoleh pada es krim kedelai hitamlidah buaya dari perlakuan kedelai hitam 5\% dan lidah buaya $3 \%$ dengan nilai $1.50 \%$. Kadar lemak es krim kedelai hitam-lidah buaya akan cenderung naik dengan semakin bertambahnya kadar kedelai hitam dalam perlakuan. Hal ini disebabkan karena kedelai hitam memiliki kadar lemak sebesar 15,0\% (Somaatmadja, 1985). Menurut Standart Nasional Indonesia (SNI, 1995), kadar lemak yang terkandung dalam es krim adalah minimal 5.0\%. Pada perlakuan es krim kedelai hitam-lidah buaya memiliki kadar protein sekitar $1.51 \%$ hingga $4.62 \%$, sehingga dapat diasumsikan bahwa es krim kedelai hitam-lidah buaya ini belum memenuhi persyaratan standart nasional indonesia.

\section{Padatan Terlarut}

Padatan terlarut tertinggi diperoleh pada es krim kedelai hitam-lidah buaya dari perlakuan kedelai hitam 25\% dan lidah buaya 3\% dengan padatan terlarut $29.33 \%$, sedangkan padatan terlarut terendah diperoleh pada es krim kedelai hitam-lidah buaya dari perlakuan kedelai hitam $5 \%$ dan lidah buaya $1.5 \%$, 3\%, dan $4.5 \%$ dengan nilai padatan terlarut $28.0 \%$. Padatan terlarut es krim kedelai hitam-lidah buaya akan cenderung naik hal ini disebabkan bertambahnya kadar kedelai hitam dan lidah buaya dalam perlakuan. Menurut Arbuckle (1996), total padatan yang rendah menyebabkan jumlah air yang membeku semakin besar sehingga udara yang terperangkap pada es krim sedikit dan pengembangan es krim akan terbatas. Selain itu, total padatan dalam es krim akan mempengaruhi sifat fisik resistensi (daya tahan leleh es krim). Lama pelelehan es krim berkaitan dengan body dan tekstur serta intensitas kemanisan (Nelson dan Trout, 1975).

\section{Kecepatan Meleleh}

Es krim yang lama meleleh diperoleh pada es krim kedelai hitam-lidah buaya dari perlakuan kedelai hitam $25 \%$ dan lidah buaya $4,5 \%$ dengan lama pelelehan 15,08 menit/10 gram, sedangkan es krim yang paling cepat meleleh diperoleh pada es krim kedelai hitamlidah buaya dari perlakuan kedelai hitam 5\% dan lidah buaya 1.5\% dengan lama pelelehan 8,58 menit/10 gram. Kecepatan meleleh es krim kedelai hitam-lidah buaya akan cenderung naik hal ini disebabkan bertambahnya lidah buaya dalam perlakuan. Menurut Yanuarda (2014), lidah buaya dapat membantu menurunkan tingkat pelelehan pada es krim. Es krim kedelai hitam-lidah buaya memiliki kecepatan meleleh berkisar antara 8,58 menit/10 gr sampai 15,08 menit/1o gr. Hasil ini membuktikan bahwa lidah buaya dapat mempengaruhi kecepatan meleleh es krim, tetapi dari data yang didapat ternyata lebih rendah dibandingkan dengan es krim komersial yang beredar di pasaran yang memiliki kecepatan meleleh 20,17 menit/10 gr (Violisa, 2012).

\section{Overrun}

Overrun diketahui bahwa semakin meningkatnya konsentrasi kedelai hitam dan lidah buaya akan menyebabkan nilai overrun pada es krim susu sari kedelai semakin rendah. Hal ini dipengaruhi oleh kekentalan suatu adonan berarti mempunyai nilai viskositas (kekentalan) yang tinggi. Adonan yang kental akan menyebabkan overrun yang rendah, karena adonan mengalami kesulitan untuk mengembang dan udara sukar menembus masuk permukaan adonan (Arbuckle, 1996). Pada pembuatan es krim kedelai hitam-lidah buaya dapat diketahui bahwa es krim memiliki overrun berkisar antara $23,39 \%$ hingga $24,51 \%$. Menurut Standart Nasional Indonesia (SNI, 1995), overrun es krim berkisar antara 70-80\% untuk skala industri, sedangkan pada pembuatan konvensional (industri rumah tangga) berkisar antara 30-50\%. Es krim kedelai hitam-lidah buaya yang dihasilkan berada di bawah kisaran tersebut, sehingga dapat dikatakan es krim tersebut kurang mampu memberikan overrun yang baik. Hal ini diduga karena es krim susu sari kedelai ini memiliki kadar lemak yang rendah. 


\section{Uji Organoleptik}

Tabel 2. Rangkuman Hasil Analisis Uji Organoleptik Es Krim Kedelai Hitam-Lidah Buaya

\begin{tabular}{cccccc}
\hline \multirow{2}{*}{$\begin{array}{c}\text { Konsentrasi } \\
\text { Kedelai Hitam }\end{array}$} & $\begin{array}{c}\text { Konsentrasi } \\
\text { Lidah Buaya }\end{array}$ & Warna & Flavor Langu & Tekstur & $\begin{array}{c}\text { Kesukaan } \\
\text { keseluruhan }\end{array}$ \\
\hline $5 \%$ & $1,5 \%$ & $2,86^{\mathrm{ab}}$ & $1,86^{\mathrm{a}}$ & $3,00^{\mathrm{a}}$ & $2,26^{\mathrm{abc}}$ \\
& $3 \%$ & $3,00^{\mathrm{a}}$ & $1,73^{\mathrm{a}}$ & $2,40^{\mathrm{a}}$ & $1,66^{\mathrm{ab}}$ \\
& $4,5 \%$ & $3,26^{\mathrm{a}}$ & $1,80^{\mathrm{a}}$ & $2,86^{\mathrm{a}}$ & $3,20^{\mathrm{abcd}}$ \\
\hline $15 \%$ & $1,5 \%$ & $2,53^{\mathrm{ab}}$ & $1,66^{\mathrm{a}}$ & $3,06^{\mathrm{a}}$ & $2,06^{\mathrm{a}}$ \\
& $3 \%$ & $3,26^{\mathrm{ab}}$ & $1,66^{\mathrm{a}}$ & $2,40^{\mathrm{a}}$ & $2,46^{\mathrm{abcd}}$ \\
& $4,5 \%$ & $3,53^{\mathrm{b}}$ & $1,80^{\mathrm{a}}$ & $2,86^{\mathrm{a}}$ & $2,86^{\mathrm{abcd}}$ \\
\hline $25 \%$ & $1,5 \%$ & $2,53^{\mathrm{ab}}$ & $1,86^{\mathrm{a}}$ & $3,06^{\mathrm{a}}$ & $2,73^{\text {cd }}$ \\
& $3 \%$ & $3,66^{\mathrm{ab}}$ & $1,46^{\mathrm{a}}$ & $2,80^{\mathrm{a}}$ & $2,60^{\mathrm{bcd}}$ \\
& $4,5 \%$ & $3,73^{\mathrm{b}}$ & $1,73^{\mathrm{a}}$ & $3,13^{\mathrm{a}}$ & $3,53^{\mathrm{d}}$ \\
\hline
\end{tabular}

Keterangan :

Warna : Angka semakin tinggi maka warna semakin kehijauan

Flavor Langu : Angka semakin tinggi maka flavor kedelai akan semakin langu

Tekstur : : Angka semakin tinggi maka tekstur semakin lembut

Kesukaan keseluruhan : Angka semakin tinggi maka es krim semakin disuka

\section{Warna}

Menurut Kartika (1988), warna merupakan salah satu profil visual yang menjadi kesan pertama konsumen dalam menilai bahan makanan. Es krim yang memiliki warna kuning kehijauan diperoleh pada es krim kedelai hitamlidah buaya dari perlakuan kedelai hitam $25 \%$ dan lidah buaya 4,5\% dengan nilai 3,73, sedangkan es krim yang memiliki warna putih diperoleh pada es krim kedelai hitam-lidah buaya dari perlakuan kedelai hitam 15\% dan $25 \%$ dan lidah buaya $3 \%$, dan $4,5 \%$ dengan nilai 2,53. Pada penelitian es krim kedelai hitam-lidah buaya ini diujikan pada 15 panelis, uji warna ini yang berwarna kuning kehijauan dipengaruhi oleh warna dari jumlah kedelai hitam yang lebih banyak dibandingkan lidah buaya.

\section{Flavor Langu}

Flavor adalah atribut dari makanan, minuman, dan bumbu-bumbuan, yang dihasilkan dari rangsangan terhadap keseluruhan indera ketika makanan melalui saluran makanan dan pernapasan, terutama rasa dan bau (Dorland and Rogers, 1997). Es krim yang memiliki aroma langu paling tinggi diperoleh pada es krim kedelai hitam-lidah buaya dari perlakuan kedelai hitam $5 \%$ dan $25 \%$ dan lidah buaya $1,5 \%$ dengan nilai 1,86 , sedangkan es krim yang memliki aroma langu paling sedikit diperoleh pada es krim kedelai hitam-lidah buaya dari perlakuan kedelai hitam $25 \%$ dan lidah buaya $3 \%$, dengan nilai 1,46 . Pada penelitian es krim kedelai hitam-lidah buaya ini diujikan pada 15 panelis dan uji aroma langu ini dipengaruhi oleh kadar dari kedelai hitam yang lebih banyak dibandingkan dengan kadar lidah buaya.

\section{Tekstur}

Tekstur es krim berhubungan dengan halus dan kasarnya kristal es dan tergantung dari udara, bentuk susunan kristal, serta ukuran dan distribusi sel-sel udara (De Man et al. 1997). Es krim yang memiliki tekstur paling lembut diperoleh pada es krim kedelai hitam-lidah buaya dari perlakuan kedelai hitam 25\% dan lidah buaya 4,5\% dengan nilai 3,13, sedangkan es krim yang memliki tekstur kurang lembut diperoleh pada es krim kedelai hitam-lidah buaya dari perlakuan kedelai hitam $5 \%$ dan $15 \%$ dan lidah buaya $3 \%$ dengan nilai 2,40. Tekstur es krim kedelai hitam-lidah buaya yang diharapkan adalah lembut. Rerata penilaian terhadap tekstur 
es krim pada konsentrasi berbeda hampir sama yaitu tekstur yang dihasilkan lembut.

\section{Kesukaan Keseluruhan}

Kesukaan secara keseluruhan merupakan salah satu aspek yang dinilai pada pengujian tingkat kesukaan panelis terhadap sifat organoleptik es krim kedelai hitam-lidah buaya. Es krim yang paling disukai diperoleh pada es krim kedelai hitam-lidah buaya dari perlakuan kedelai hitam 25\% dan lidah buaya 4,5\% dengan nilai 3,53, sedangkan es krim yang paling tidak disukai diperoleh pada es krim kedelai hitamlidah buaya dari perlakuan kedelai hitam $5 \%$ dan lidah buaya $3 \%$ dengan nilai 1,66. Komponen-komponen cita rasa membuat panelis lebih menyukai produk, komponen yang sangat penting adalah timbulnya perasaan seseorang setelah makan (Winarno, 1993) dan penilaian tingkat kesukaan secara numerik sangat dipengaruhi oleh panelis.

\section{KESIMPULAN}

Perbedaan konsentrasi kedelai hitam pada perlakuan berpengaruh terhadap aktivitas antioksidan. Es krim kedelai hitam - lidah buaya dengan komposisi terbaik adalah $25 \%$ kedelai hitam dan lidah buaya 3\% karena memiliki aktivitas antioksidan yang tertinggi yaitu sebesar $37,34 \%$. Pada perlakuan ini mengasilkan kadar protein 9,40\%, kadar lemak 4,61\%, padatan terlarut $29,33 \%$, kecepatan meleleh 11.00 menit/10 gram, dan overrun 23,39\% dan lidah buaya dapat berpengaruh terhadap kecepatan meleleh es krim. Semakin tinggi kandungan lidah buaya semakin tinggi pula kecepatan melelehnya.

\section{DAFTAR PUSTAKA}

[BSN]. Badan Standarisasi Nasional. 1995. Es krim. SNI o1-3713-1995. Jakarta: Badan Standarisasi Nasional.

Bodyfelt F., Tobias J., dan Trout G. 1998. The Sensory Evaluation of Diary Product. New York: Van Nostard Reinhold.

De Man, John M. 1997. Kimia Makanan. Terjemahan Prof. Dr. Kokasih Padmawinata. Bandung: Institut Teknologi Bandung.
Dorland, W. E and Rogers, J. A. 1997. The Fragrance and Flavour Industry. New York : Wayne E. Dorland Co.

El-Zairy, E. M. R., 2011. New Thickening agent based on Aloe vera Gel for disperse Printing of Poyester X.AUTEX Research Journal. 11(2):66-70

Furnawanthi, I., 2002. Khasiat dan Manfaat Lidah Buaya Si Tanaman Ajaib. Jakarta: Agromedia Pustaka.

Hasler, C.M. 1998. Functional Foods : their role in disease prevention and health promotion. Food Tech. 52(11): 63-70.

Inges, K., 2009. Kesehatan Reproduksi Es Krim Menyuburkan Rahim. "Makalah Kebidanan"

Marshall, R.T., dan W. S., Arbuckle, 1996. Ice Cream 5th Edition. New York: Chapman $\&$ Hall.

Mojohnier, T. dan Troy, H.C. 1993. The Technical Control of The Diary Product. Chicago: Mojohnier Bross. Co.

Muchtadi, D. 2010. Kedelai Komponen Bioaktif untuk Kesehatan. Bandung. Alfabeta.

Nelson, J. A. and Trout, G. M. (Eds). 1975. Judging Dairy Products 4th. Milkwakee: The Olsen Publising Co.

Pramitasari, D. 2010. Penambahan Ekstrak Jahe (Zingiber officinale rosc.) Dalam Pembuatan Susu Kedelai Bubuk Instan Dengan Metode Spray Drying : Komposisi Kimia, Sifat Sensori dan Aktivitas Antioksidan. Skripsi. Program Studi Teknologi Hasil Pertanian, Fakultas Pertanian, Universitas Sebelas Maret.

Putri, D. 2015. Karakteristik Fisikokimia dan Sensori Es Krim Kacang merah (Phaseolus vulgaris $L$ ) dengan variasi penambahan bubuk kelopak bunga rosella. Jurnal Ilmiah Teknologi dan Industri Pangan UNISRI 1(1):1-8

Santi, K. 2017. Pengaruh Substitusi Susu Kedelai dan Tepung Mocaf Terhadap Daya Terima, Nilai Gizi dan Nilai Ekonomi pada Es Krim. Skripsi. Surabaya :Universitas Air Langga

Somaatmadja, S., 1985. Kedelai Hitam. Badan Penelitian dan Pengembangan Pertanian. Bogor: Pusat Penelitian dan 
Pengembangan Tanaman Pangan.

Sudarmadji, S., B. Haryono, dan Suhardi, 1997. Prosedur Analisa untuk Bahan Makanan dan Pertanian. Yogyakarta: Liberty.

Suharyanto, 2009. Pengolahan Bahan Hasil Ternak. Skripsi. Bengkulu: Universitas Bengkulu.

Sundari, T. dan E. A. Saati. 2009. Pembuatan Es Krim Lidah Buaya (Aloe chinensis) dengan Penambahan Gelling Agents. Skripsi. Malang: Universitas Muhammadiyah Malang.

Violisa, A. 2012. Penggunaan Rumput Laut Sebagai Stabilizer Es Krim Susu Kedelai. Skripsi. Surakarta. Universitas Sebelas Maret

Winarno, 1993. Pangan Gizi Teknologi dan Konsumen. Jakarta: PT Gramedia Pustaka Utama
Kartika, B., Hastuti, D., dan Supratno, W., 1988. Pedoman Uji Inderawi Bahan Pangan. Yogyakarta: PAU Pangan dan Gizi Universitas GadjahMada.

Pomeranz,Y., dan Meloan, C.E., 1980. Food Analysis: Theory and Practice Second Edition. New York: Van Nostrand Reinhold Company.

Yanuarda, A., 2014.Pengaruh Tingkat Penggunaan Gel Lidah Buaya (Aloe barbadensis Miller) sebagai stabilizer pada Es Krim yang ditinjau dari Viskositas, Kecepatan Meleleh, Overrun dan Total Padatan. Skripsi.Malang:Universitas Brawijaya

Yen, G.O. and Chen, Y., 1995. Antioxidant Activity of Various Tea Extracts in Relation to Their Antimutagenicity. Journal of Agricultural and Food Chemistry.43(1): 27-32. 